Pamiętnik Literacki 2013, 4, s. 35-52
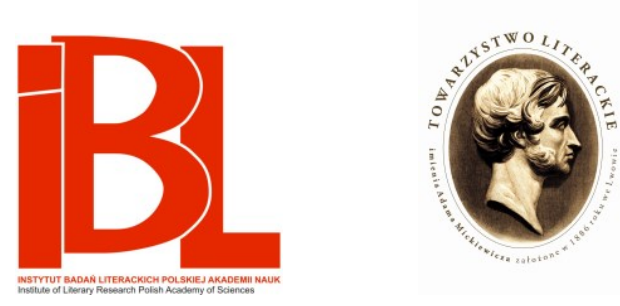

\title{
Pamięć w perspektywie radykalnego konstruktywizmu
}

Bogdan Balicki 
Pamiętnik Literacki CIV, 2013, z. 4 PL ISSN 0031-0514

BOGDAN BALICKI

(Uniwersytet Szczeciński)

\section{PAMIECĆ W PERSPEKTYWIE RADYKALNEGO KONSTRUKTYWIZMU*}

Niniejsza syntetyczna prezentacja stanowiska konstruktywistycznego odnośnie do zagadnienia pamięci nie jest prezentacją konsekwencji zastosowania domkniętej i ustrukturyzowanej doktryny filozoficznej, bo w żadnym razie za taką nie

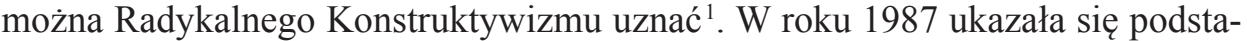
wowa dla tego nurtu książka pod redakcją Siegfrieda J. Schmidta pt. Dyskurs Radykalnego Konstruktywizmu ${ }^{2}$ - i dyskursem właśnie, mimo że okres najważniejszych debat na ten temat już minął, Radykalny Konstruktywizm wciąż jest: dyskursem, dostatecznie jednolitym, by można było o nim mówić, i nie dość jednolitym, by stał się niezależnym nurtem badawczym. Taka forma tego nurtu pozwala na owocne stosowanie jego heurystyk w naukach szczegółowych - co potwierdza jego przeszło 20-letnia już recepcja w humanistyce, a co nie jest przecież niczym niezwykłym w historii myśli filozoficznej i naukowej. Z drugiej strony, mówienie o Radykalnym Konstruktywizmie, zwłaszcza poza obszarem nauki niemieckiej, gdzie zadomowił się on w sposób wyjątkowy, natrafia na barierę licznych niedomówień i uprzedzeń, związanych już to z bliskością pewnych znanych koncepcji naukowych (jak konstruktywizm społeczny Bergera i Luckmanna ${ }^{3}$ ), już to z dystansem, który oddziela konstruktywistyczne modele świadomości, poznania czy kultury itd. od realistycznych koncepcji filozoficznych i zdroworozsądkowych oglądów rzeczywistości. Większość więc prac tego nurtu ma do pokonania już na starcie kilka zasadniczych trudności, wśród których najważniejsze to niejednorodność, kłopot z klasyfikacją i konieczność innego oglądu problemów, które zdołały się utrwalić w humanistyce europejskiej. Choć w języku polskim

* Opracowanie powstało jako część badań, które zostały sfinansowane ze środków Narodowego Centrum Nauki, przyznanych w ramach finansowaniu stażu po uzyskaniu stopnia naukowego doktora, na podstawie decyzji numer DEC-2012/04/S/HS2/00325.

1 Warto w tym miejscu wskazać na artykuł E. Kuźmy (Pamięć w listach a pamięć we wspomnieniach 〈na przykładzie listów Stanisława Przybyszewskiego i jego ksiażki „Moi wspótcześni”’〉. W zb.: Poetologie pamięci. Red. D. Śnieżko. Szczecin 2011), który również odnosi się do konstruktywistycznej koncepcji pamięci w wersji N. Luhmanna.

2 Der Diskurs des Radikalen Konstruktivismus. Hrsg. S. J. S c h m i d t. Frankfurt am Main 1987.

3 Zob. P. L. B e rge r, T. L u c k m a n n, Społeczne tworzenie rzeczywistości. Traktat z socjologii wiedzy. Przeł., wstęp J. N i żn i k. Warszawa 1983. 
istnieje już kilka ciekawych ofert wydawniczych ${ }^{4}$, które kompleksowo wprowadzają do tej tematyki, to intuicja przemawia za tym, że Radykalny Konstruktywizm (dalej: RK) ciągle nie jest elementem normal science polskiej humanistyki. Dlatego, żeby uniknąć niepotrzebnego zamykania się w wąskiej enklawie znawców (znawcy odcięci od otoczenia łatwo zamieniają się w wyznawców), także i w tym miejscu warto jeszcze raz przypomnieć charakterystykę tego nurtu, tym bardziej że z koncepcją pamięci wiąże się interesujący epizod w jego historii.

\section{Najkrócej, jak się da - Radykalny Konstruktywizm}

Przede wszystkim - RK nie ma nic wspólnego ze strywializowanym solipsyzmem i relatywizmem, według których wszystko, co nas otacza, jest naszą ,konstrukcją" i jest zrelatywizowane tylko i wyłącznie do naszej woli. O tym, jak dalecy od takiej opinii są konstruktywiści, niech świadczy fakt, że w żadnym z klasycznych dzieł owego nurtu nie pojawiła się definicja słowa „,konstrukt”. Najłatwiej zdefiniować główne, teoriopoznawcze założenie RK w odniesieniu do zdroworozsądkowych poglądów na poznanie, określanych w filozofii mianem naiwnego lub hipotetycznego realizmu. Pogląd ten zakłada nieusuwalny dualizm między podmiotem poznającym a obiektem poznawanym ${ }^{5}$. Dualizm ów opiera się $\mathrm{w}$ istocie na prostej, transmisyjnej koncepcji - obserwator za pomocą narzędzi poznawczych dokonuje oglądów zewnętrznej względem niego rzeczywistości, która jest uprzednia względem poznania. Większość koncepcji teoriopoznawczych uznaje to założenie za nieproblematyczne, zajmując jedynie odmienne stanowiska w kwestii tego, jak obserwator to czyni. Jakich używa narzędzi? Jakie są jego cele? Jak kumuluje zdobytą w ten sposób wiedzę? Jakie zakłócenia mogą się pojawić w procesie poznania (lub węziej - percepcji) itd.? Od klasycznych koncepcji realistycznych, opartych na Arystotelesowskiej definicji prawdy (zgodność sądu z rzeczywistością) po zdania protokolarne Koła Wiedeńskiego - ambicją nauki i filozofii była zawsze chęć dotarcia do poznania czystego, niezapośredniczonego, prawdziwego: poznania, które wolne od wszelkich zakłóceń leży u podstaw ludzkiego rozumu. Konstruktywizm stawia dokładnie te same pytania o to, jak funkcjonuje nasz aparat poznawczy, nie czyni jednakże założenia o dualizmie przedmiotu i podmiotu, upraszczając właściwie ten schemat: poznanie jest działaniem obserwatora - wszystko inne to pochodne tego procesu.

Konstruktywistyczny pogląd na poznanie nie wziął się znikąd. Do jego ukształtowania się doprowadziło zetknięcie się kilku koncepcji filozoficznych i ściśle naukowych. W planie tradycji filozoficznej konstruktywizmu umieścić należy m.in. niektóre sądy presokratyków dotyczące natury poznania, poglądy Berkeleya, ka-

4 Warto zwrócić uwagę przede wszystkim na dwie antologie, które udostępniają w języku polskim źródłowe teksty z tego nurtu: Konstruktywizm $w$ badaniach literackich. Red. E. Kuźma, A. Skrendo, J. Madejski. Kraków 2006. - Radykalny Konstruktywizm. Antologia. Red. B. Balicki, D. Lewiński, B. Ryż, E. Szczerbuk. Wrocław 2010.

5 Josef Mitterer, filozof kojarzony z konstruktywizmem, choć deklarujący konsekwentnie swój dystans do głównego nurtu RK, twierdzi wręcz, że dualizm ten jest pozycją wyjściową całej filozofii europejskiej, kanwą wszystkich koncepcji teoriopoznawczych oraz źródłem nieusuwalnych problemów filozoficznych. Zob. J. M i t t e r e r: Tamta strona filozofii. Przeł. M. Ł u k a s i e w i c z. Warszawa 1996; Ucieczka z dowolności. Przeł. A. Z e i d l e r - J a n i s z e w s k a. Warszawa 2004. 
tegorie poznawcze Kanta, a także, mało u nas znaną, filozofię Hansa Vaihingera ${ }^{6}$, który utrwalił w dyskursie filozoficznym pojęcie „fikcji poznawczej”. W planie naukowym zaś - przede wszystkim tradycję cybernetyki pierwszego i drugiego rzędu (Heinz von Foerster), teorię systemów (Ludwig von Bartallanfy, Norbert Wiener), epistemologię ewolucyjną Jeana Piageta (rozwijaną w konstruktywizmie przez Ernsta von Glasersfelda), systemową koncepcję organizacji form życia (Humberto R. Maturana, Francisco Varela) oraz neurobiologiczny model funkcjonowania mózgu oparty na koncepcji samoreferencji (Gerhard Roth, Wolf Singer). Nurt jako taki narodził się w Stanach Zjednoczonych, za jego ojców-założycieli uznać należy Foerstera i Glasersfelda - obaj uczeni wywodzą swój życiorys naukowy z XX-wiecznych prac nad matematycznymi koncepcjami języka i umysłu. Co ciekawe, RK nie doczekał się jednak należytej recepcji ani w Stanach, ani W większości krajów europejskich, co spowodowane być mogło m.in. zupełnie odmiennymi tendencjami w filozofii i naukach humanistycznych tych obszarów. RK krystalizował się mniej więcej wtedy (lata siedemdziesiąte i osiemdziesiąte $\mathrm{XX}$ wieku), kiedy na popularności zyskiwały koncepcje niekiedy określane zbiorczo jako postmodernizm - postmoderniści zwalczali fundamentalizm naukowy, kwestionując nie tylko tradycje pozytywistyczne w nauce, lecz naukę jako taką; przedstawiciele konstruktywizmu, krytykując nieuświadamiane często ontologiczne poglądy na prawdę naukową, oferowali zamiast porzucenia ideałów nauki powrót do racjonalności naukowej, jednakże w oparciu o inne założenia teoriopoznawcze. W oczach większości humanistów, czego dowodzą żywiołowe dyskusje także w Niemczech, gdzie RK zakotwiczył się najmocniej, oferta konstruktywizmu, choć naukowa, była o wiele groźniejsza niż koncepcje np. Derridy, bo znosiła nie tylko stare opozycje między naturalizmem a antynaturalizmem metodologicznym, lecz także (zwłaszcza koncepcja Empirycznej Nauki o Literaturze przedstawiona przez Schmidta, który RK uczynił zapleczem filozoficznym dla literaturoznawstwa $^{7}$ ) podział na nauki humanistyczne i przyrodnicze, głosząc, że poglądy np. na społeczeństwo i rolę jednostki wywieść można z koncepcji biologicznych, nie popadając przy tym w redukcjonizm, jak to miało miejsce w przypadku behawioryzmu.

Asumptem do powstania konstruktywistycznego modelu umysłu jako systemu zamkniętego operacyjnie, było m.in. znane już od dawna odkrycie przez Johannesa Müllera tzw. niespecyficzności potencjału nerwowego. Okazało się, że mimo iż organizm żywy postrzega zewnętrzny wobec niego świat za pomocą zmysłów, to cała różnorodność tego świata znika tuż po akcie percepcji zmysłowej: wszystkie sygnały odbierane np. przez oko (natężenie światła) są przetwarzane od razu na wewnętrzny język systemu nerwowego, który jest najprostszym możliwym kodem, zawierającym jedną tylko różnicę - kodem binarnym. Jak pisał Foerster, świat

6 H. Ve i hi ng e r, Die Philosophie des Als Ob. Lipsk 1927.

Zob. S. J. S c h m i d t: Grundriß der Empirischen Literaturwissenschaft. Frankfurt am Main 1980; Dlaczego empiryczne badania literackie? Dlaczego nie? Przeł. A. Z a w is z e w s k a. „Pamiętnik Literacki” 2008, z. 2. - B. B a l i c k i: Siegener Konstruktivismus i Konstanzer Schule, czyli o dwóch szkołach badania recepcji tekstów literackich. W zb.: Obserwacje systemu i badania empiryczne. Wiedza o literaturze z punktu widzenia obserwatora II. Red. B. Balicki, D. Lewiński, B. Ryż, E. Szczerbuk. Wrocław 2006; Empiryczna Nauka o Literaturze - kierunek $w$ badaniach literackich i szkoła naukowa. „Teksty Drugie” 2010, nr 4. 
kolorów, zapachów, wrażeń i doświadczeń to dla mózgu tylko klik, klik, klik ${ }^{8}$. Jeżeli tak jest, to powstaje pytanie: skąd bierze się wiedza o złożoności świata w „maszynie”, która działa w oparciu o tak prosty język? Z pomocą przyszła systemowa koncepcja organizacji życia, sformułowana najdokładniej przez Maturanę ${ }^{9}$, chilijskiego neurobiologa, współpracownika Foerstera. Maturana uznał za nierozłączne zasady funkcjonowania organizmu żywego oraz prawidła jego działań poznawczych - źródłem wszystkiego jest zasada autopojezy, zgodnie z którą do zaistnienia życia konieczne są miliony procesów chemicznych sprzężonych ze sobą autokatalitycznie w taki sposób, że same wytwarzają warunki do swojej aktywności. Ta koncepcja thumaczy organizację życia (a także, jak się za chwilę przekonamy - poznania) bez odniesienia do zewnętrznych podmiotów sprawczych. System organizuje się sam w celu utrzymania swojej organizacji, a z czasem różnicuje się coraz bardziej, podlegając procesom ewolucji, które selektywnie pozwalają trwać tylko systemom lepiej zorganizowanym, tj. potrafiącym wytworzyć wystarczającą ilość zachowań koniecznych do przetrwania. Zróżnicowaniu ewolucyjnemu organizmów żywych nie ma właściwie końca, są to jednakże w każdym momencie procesy samorzutne, podporządkowane prawom termodynamiki, oparte na zasadzie samoorganizacji. O ile cały organizm wytwarza sam swoją strukturę, pobierając z zewnątrz tylko energię, o tyle w jego obrębie powstają systemy (np. układ trawienny), które już samosterowne nie są, a także takie, które choć wytworzone przez system biologiczny, mają względem niego znaczący obszar autonomii - takim systemem (tym razem samoreferencyjnym, a nie autopojetycznym) jest system nerwowy. System nerwowy odpowiada za obszar kognicji, a więc obszar produkowania, testowania i wdrażania modeli działań, które służą przetrwaniu całego organizmu. Zasada samoreferencji tego systemu głosi, że wszystkie swoje operacje odnosi on wyłącznie do innych swoich operacji, zmysłów zaś używa do obserwacji otoczenia, z tym jednakże warunkiem, że wszelkie działania zmysłów oraz ich efekty są w pełni i od początku podporządkowane strukturze systemu nerwowego jako całości. $Z$ tego poziomu jednakże daleko jeszcze do problemu świadomości, a blisko do uzasadnionego w tym kontekście podejrzenia o solipsyzm.

Nie budzi już dziś kontrowersji pogląd, że życie nie zaczyna się od jednego organizmu, lecz zawsze od populacji. Populacyjność oznacza, iż organizmy żywe, jakkolwiek autonomiczne dzięki zasadzie autopojezy, zawsze występują w otoczeniu podobnych organizmów żywych, z którymi łączy je równoległa struktura. Maturana określa to zjawisko jako proces: paralelizacja struktur systemów zamkniętych jest koniecznym warunkiem udanej interakcji i oznacza, że od samego początku organizmy żywe obserwują w swoim otoczeniu dwa rodzaje fenomenów - środowisko, z którego pobierają energię i które jest jednocześnie źródłem zagrożeń, oraz inne, podobne organizmy żywe, z którymi współoddziaływanie zwiększa szansę na przetrwanie w środowisku. Sprawia to, że wraz z ewolucją systemu

8 H. vo n Foerster, O konstruowaniu rzeczywistości. Przeł. B. Palu s. W zb.: Radykalny Konstruktywizm.

9 Zob. m.in. H. R. M a tu r a n a: Erkennen: Die Organisation und Verkörperung von Wirklichkeit. Ausgewählte Arbeiten zur biologischen Epistemologie. Wyd. 2. Braunschweig-Wiesbaden 1985; Ontologia obserwacji. Biologiczne podstawy samoświadomości i fizykalna dziedzina egzystencji. Przeł. B. Ry ż. W zb.: Radykalny Konstruktywizm. - H. R. M a t u r a n a, F. Va r e la, Der Baum der Erkenntnis. Die biologischen Wurzeln des menschlichen Erkennens. Bern 1987. 
ożywionego dokonuje się jednocześnie - oczywiście na różne sposoby i z różnym efektem - ewolucja populacyjności jako nieodzownego warunku życia. I także za ten obszar aktywności odpowiada system nerwowy, co oznacza, że w systemie nerwowym kształtuje się pole operacji (zawsze opartych na kodzie binarnym) odpowiedzialne za generowanie i walidowanie działań w sferze interakcji z innymi organizmami. Peter M. Hejl, który rozwija biologiczną koncepcję Maturany na polu koncepcji społecznych, postawił hipotezę, że silny rozwój tej sfery aktywności mózgowej u człowieka sprawił, iż nasz gatunek stanął przed pewnym zagrożeniem: oto mózg, część systemu nerwowego odpowiedzialna za kluczowe procesy związane z przetrwaniem, zaczął wytwarzać zbyt dużo modeli zachowań, przy niedostatecznej liczbie kryteriów ich walidacji ${ }^{10}$. Z pomocą znów przyszły procesy samoorganizacji - aby móc porządkować swoje zachowania, pozostające w interakcji organizmy żywe poddały się procesowi samoreferencji, a więc obserwacji obserwacji, na poziomie ponadindywidualnym. Innymi słowy, rosnące skomplikowanie mózgu wymusiło powstanie systemu zachowań w ramach populacji, który w procesie rozwoju stawał się coraz bardziej skomplikowany.

To jest kluczowy moment dla zrozumienia istoty konstruktywistycznego poglądu na poznanie: nasz obszar kognicji, oparty na działaniu milionów sprzężonych ze sobą komórek nerwowych, rozwija się wraz z rozwojem sfery odpowiedzialnej za interakcję z innymi, podobnymi organizmami poprzez paralelizację struktur poznawczych. Zatem operacja konstruowania rzeczywistości przeżywanej, jakkolwiek odbywa się w systemie autonomicznym, korelowana jest za sprawą interakcji, a więc i komunikacji, z równoległą konstrukcją rzeczywistości, która zachodzi w innym, również autonomicznym systemie kognicji. Te uwspólnione procesy prowadzą do powstania symbolicznej sfery interakcji, a jednym z jej szczytowych osiągnięć jest wytworzenie języka naturalnego - znów systemu do pewnego stopnia autonomicznego, który jednocześnie pozwala znosić ograniczenia związane $\mathrm{z}$ autonomią indywidualną i zawiera (jako zbiór zachowań komunikacyjnych) cały szereg modeli działań, schematów pojęciowych, a także - wiemy to dzięki osiągnięciom również polskiego językoznawstwa ${ }^{11}$ - językowy obraz świata. Powstanie języka naturalnego, który ostatecznie jest zawsze realizacją określonych operacji kognitywnych, umożliwiło nam wreszcie obserwację samych siebie i pozwoliło na wytworzenie obszaru kognitywnego, określanego jako świadome „ja”. Świadomość wynika ściśle ze społecznej tożsamości człowieka, który postrzega siebie - zarazem swoją odrębność i przynależność - poprzez intersubiektywnie wypracowane wzory komunikacji. Tę paradoksalną sytuację, w której się znajdujemy stojąc pomiędzy systemem biologicznym a społecznym, dobrze oddaje tytuł książki Siegfrieda J. Schmidta Kognitive Autonomie und soziale Orientierung (Autonomia kognitywna i orientacja społeczna) ${ }^{12}$.

Systemowe koncepcje życia, kognicji i społeczeństwa doczekały się w ramach RK wielu opracowań, omówień i dyskusji. Znaleziono także w tradycji nauki

${ }^{10}$ P. M. H e j 1: Soziale Konstruktion von Wirklichkeit. W zb.: Die Wirklichkeit der Medien: Eine Einführung in die Kommunikationswissenschaft. Hrsg. K. M e rte n, S. J. S c h m idt, S. W e i s c h e n b e r g. Opladen 1994; Universalien und Konstruktivismus. Frankfurt am Main 2001. 2000 .

${ }_{11}$ Zob. m.in. Językowy obraz świata i kultura. Red. J. Anusiewicz, A. Dąbrowska. Wrocław

${ }^{12}$ S. J. S c h m i d t, Kognitive Autonomie und soziale Orientierung. Frankfurt am Main 2003. 
i filozofii liczne poglądy, które zgadzają się z tą koncepcją, choć dotychczas pozostawały raczej na marginesie głównego nurtu nauki. Nie dotyczy to, oczywiście, kantyzmu ani filozofii późnego Wittgensteina. Nie musimy jednak szukać daleko, by odnaleźć „konstruktywistę” - w pełnym znaczeniu tego słowa, choć bez żadnego potwierdzonego kontaktu z RK, konstruktywistyczne poglądy na naturę poznania miał Ludwik Fleck, który najtrafniej opisał proces konstruowania wiedzy jako wybitnie kolektywny. Niektóre fragmenty prac Flecka, zwłaszcza gdy pisze on np. o problemie rzeczywistości, mogłyby z powodzeniem wyjść spod ręki Foerstera czy też Glasersfelda ${ }^{13}$.

Wracając na chwilę do historycznych początków RK warto w tym miejscu wspomnieć o doktoracie Heinza von Foerstera, dorastającego w przedwojennym Wiedniu. Pochodził on z bogatej, mieszczańskiej rodziny, zaprzyjaźnionej blisko z rodziną Wittgensteinów, samego Ludwika Wittgensteina traktował jak wujka i jako nastolatek znał na pamięć cały Traktat logiczno-filozoficzny. Ukończył fizykę na Uniwersytecie Wiedeńskim i jego myśl filozoficzna wywodzi się właśnie z tego kręgu. Zanim wyemigrował w 1946 r. do Stanów Zjednoczonych, napisał pracę doktorską Das Gedächtnis. Eine quantephysikalische Untersuchung (Pamięć. Dociekania kwantowo-fizykalne) ${ }^{14}$. Praca nie doczekała się kontynuacji ani nie była tak przełomowa, jak chciał tego autor, z kilku jednak względów stała się początkiem nowego, powiedzielibyśmy za Fleckiem, stylu myślowego. Konceptualizacja pamięci u Foerstera opierała się m.in. na tezie o biotechnicznie uformowanych, analogicznie do genów, elementach pamięci, które dziś nazwalibyśmy „memami”. Jednak najbardziej znaczące było twierdzenie Foerstera, że problemy nauk biologicznych i fizycznych mogą zostać wyjaśnione za pomocą koncepcji, argumentów i empirycznych dowodów fizyki oraz chemii.

Podsumowując i dopowiadając: poznanie, a więc funkcjonowanie obszaru kognicji jest według koncepcji RK ściśle związane z biologiczną strukturą organizmu; poznajemy, wytwarzając w naszych obszarach kognitywnych „namacalną”

${ }^{13}$ Zob. L. F 1 e c k, O kryzysie „,rzeczywistości”. W: Psychosocjologia poznania naukowego. Powstanie i rozwój faktu naukowego oraz inne pisma z filozofii poznania. Lublin 2006 (przeł. W. A. N i e m i r o w s k i): „Do idealnej »absolutnej« rzeczywistości nie zbliżamy się nawet asymptotycznie, gdyż zmienia się ona ustawicznie, odnawia się i oddala się od nas w tym samym stopniu, w jakim kroczymy naprzód. Jest to wyśniony ideał, którego treść określana jest jedynie poprzez przeczenie, poprzez tęsknotę za czymś innym. [...] Z egzystencji praw przyrody, których treść nie da się wyprowadzić wyłącznie z obeznanego z filozofią umysłu współczesnego Europejczyka, nie można wyprowadzić wniosków o istnieniu absolutnej rzeczywistości. Istnieją także prawa etyczne, zwyczaje kupieckie, naganne zachowanie polityczne, nie dające się wyprowadzić z żadnego dzisiejszego umysłu. Czy w tym miejscu mam też wierzyć w »absolutną egzystencję«, w deus ex machina, którego odbiciem są prawa i zasady? Nie widzę żadnej pryncypialnej różnicy, gdyż nie ma prawa bez wyjątków, wszystkie są uwarunkowane kulturą, a więc zależne od rozwoju, zastępowalne przez inne, sensowne lub niedorzeczne, w zależności od punktu widzenia krytyka”.

${ }_{14}$ Praca została przedrukowana w wydanym niedawno tomie: H. v o n F o e r s t e r, A. M ü l$1 \mathrm{e} \mathrm{r,} \mathrm{K.} \mathrm{H.} \mathrm{Mü} 11$ e r, Radikaler Konstruktivismus aus Wien. Eine kurze Geschichte vom Entstehen und vom Ende eines Wiener Denkstils. Wien 2013. Książka ta jest interesująca z dwóch względów - przede wszystkim pokazuje tradycje przedwojennego środowiska naukowego związanego z Wiedniem, wywodząc główne czynniki rozwoju konstruktywizmu ze spuścizny E. Macha, O. Neuratha czy Koła Wiedeńskiego. Autorzy do opisu tych zjawisk wykorzystują jednakże terminologię i koncepcję stylu oraz „kolektywu myślowego” L. Flecka - Fleck, który zainspirował Th. Kuhna do napisania Struktury rewolucji naukowych, wypiera najwyraźniej jego koncepcję paradygmatu i rewolucji. 
rzeczywistość, która z pragmatycznego punktu widzenia jest wiązką modeli działania w środowisku; nasza konstrukcja rzeczywistości opiera się zarówno na autonomii poszczególnych systemów kognitywnych, jak i na współorientacji społecznej za pomocą symbolicznych narzędzi komunikacyjnych, wykazujących również cechy systemu samoreferencyjnego (język naturalny); porządki organizacji społecznej, kognitywnej i biologicznej, które można wyjaśniać jednolitym językiem teorii systemów, choć ściśle się ze sobą wiążą, są do siebie niesprowadzalne (konstruktywizm nie jest w tym sensie redukcjonizmem). Poznanie naukowe nie okazuje się zatem poznaniem prawdy, lecz działaniem społecznym, które tym się różni od innych, podobnych mu działań, że opiera się na bardziej złożonych i restrykcyjnych kryteriach oceny osiąganych wyników. Naukowy pogląd na świat nie jest więc jakościowo odmienny od poglądów zdroworozsądkowych czy nienaukowych (antyfundamentalizm naukowy RK), lecz jedynie wynika z działania jednostek społecznych w szczególnym subsystemie społecznym, który wytwarza inne kryteria poznania. W RK, choć często oskarża się go o relatywizm poznawczy, szczególnego znaczenia nabiera pojęcie etyki naukowej, jako niezbywalnego regulatywu komunikacji w tym obszarze społecznym. Skoro wiedza konstruowana jest wewnątrz (systemu kognitywnego czy też społecznego), to redefinicji podlega także rozumienie empirii i pozyskiwania wiedzy. Mówiąc w wielkim skrócie: w ramach RK miarą empiryczności nie jest możliwie niezakłócone dotarcie do zewnętrznych bytów, transcendentnych względem kognicji, lecz intersubiektywność - o naturze wytwarzanej wiedzy decydują wewnątrzsystemowe kryteria jej oceniania i zastosowanie w praktyce życiowej. W tym kontekście unieważnia się podział na nauki empiryczne i nieempiryczne (czy też na Naturwissenschaften i Geisteswissenschaften), ponieważ produkt finalny każdego procesu poznawczego zależy od sposobów wytwarzania i walidacji, a nie od zewnętrznego względem poznania stanu rzeczy (odpowiednio natury i kultury). Empiryczność, podobnie jak intersubiektywność, staje się zatem kwestią stopnia, a nie decyzji „,tak” lub „nie" ${ }^{15}$.

$\mathrm{Na}$ zakończenie tego możliwie najkrótszego zarysu stanowiska RK warto dodać, wychodząc naprzeciw obawom o zgubne naturalizowanie problemów humanistycznych, że społeczności konstruktywistów nie udało się uniknąć pewnego ważkiego rozłamu. RK startował jako interdyscyplinarny projekt, który jednym językiem nauki miał objąć fenomeny opisywane zazwyczaj przez różne porządki poznawcze. Np. neurofizjologia i psychologia mają do pewnego stopnia zbieżny obszar badawczy, zważywszy jednak, że operują różnymi językami (a jak wiemy, język to nie tylko medium komunikacji, lecz także nieodzowny element każdej struktury społecznej, przechowujący wzory działań i kodujący odmienności), ich współpraca natrafia na znaczącą granicę. Dziś RK rozwija się dwutorowo: z jednej strony, jako dziedzina określana czasem mianem biofilozofii, skupia się na neurobiologicznych warunkach kognicji, z drugiej - jako epistemologia niedualistyczna znalazł zastosowanie zarówno w pedagogice i psychologii, jak i w nowoczesnych badaniach literatury, komunikacji społecznej oraz mediów ${ }^{16}$.

15 Zob. S. J. S c h m i d t, Die Zähmung des Blicks: Konstruktivismus, Empirie, Wissenschaft. Frankfurt am Main 1998.

${ }^{16}$ Zob. przywoływany już tom Die Wirklichkeit der Medien. 


\section{Pamięć z perspektywy mózgu}

Autorem najbardziej doniosłych prac w ramach RK dotyczących działania ludzkiego mózgu jest Gerhard Roth, który w licznych publikacjach zaproponował model mózgu jako dynamicznej sieci ${ }^{17}$. Roth charakteryzuje główny organ systemu nerwowego człowieka jako strukturę komórek nerwowych, których liczba przemnożona przez możliwość połączeń międzykomórkowych daje w praktyce nieograniczoną wręcz pojemność. Jednocześnie jest to system cechujący się ogromną organizacją, której pełny model, mimo szybkiego postępu nauk neurologicznych, wciąż nie jest dostępny. Pytanie o porządek w tym systemie natrafia, zdaniem Rotha, na szereg kwestii, które podzielić można z grubsza na trzy obszary. Otóż mózg podlega determinacji ze strony trzech strukturalnych prądów: determinacji genetycznej, epigenetycznej oraz środowiskowej. Według Rotha najważniejsza jest determinacja epigenetyczna i to ona sprawia, że system nerwowy jest systemem zamkniętym operacyjnie ${ }^{18}$. Gdyby działo się inaczej, mózg byłby maszyną trywialną (jak automat do kawy), tj. wykonywałby jedynie zaprogramowane w kodzie genetycznym działania lub podlegał warunkowaniu środowiskowemu. Tymczasem informacje zapisane $\mathrm{w}$ genach oraz warunki zewnętrzne wobec organizmu to tak naprawdę granice jego autonomii, która jest nieodzowna do generowania zachowań.

Ontogeneza mózgu nie przebiega według żadnego przewidzianego wcześniej planu. Roth pisze, że porządek mózgu rozwija się poprzez kaskady sprzężonych ze sobą procesów samoorganizacji i samoróżnicowania, które u swojej podstawy mają proste operacje neuronalne.

Najważniejsze jest [...] to, że kryteria stabilizacji oraz zmiany w mózgu muszą pochodzić od niego samego [...]. Nie ma w mózgu żadnej wyższej płaszczyzny decyzji i kontroli poza doświadczeniem samego siebie [Selbsterfahrung]. Kwestia, w jaki sposób aktywność sieci nerwowej powinna być kontrolowana i korelowana, rozstrzyga się w mózgu w oparciu o w c ze śn i j s ze akty w n oś c i. Oznacza to, że mózg organizuje siebie na podstawie swojej własnej historii. To jest to, co się określa mianem „samoreferencyjności”. Procesy samoorganizacji są zatem koniecznym założeniem samoreferencji ${ }^{19}$.

Zamknięcie operacyjne i samoreferencyjność mózgu mają źródło w tym, że kontroluje on swoje procesy za pomocą własnych doświadczeń. Pamięć - jak wielokrotnie podkreśla Roth - jest w związku z tym naszym najważniejszym organem zmysłowym. Jednakże zanim pamięć zostanie uruchomiona, treści postrzegania muszą zostać sprawdzone co do stopnia ich nowości i ważności, kryteria te zaś znów pochodzą z wcześniejszych doświadczeń, co prowadzi do oczywistego paradoksu:

popadamy w pozorne błędne koło, które charakteryzuje samoreferencyjność jako naczelną zasadę organizacji mózgu. Zasada ta mówi, że musi on samodzielnie rozwinąć kryteria, według których ocenia swoją aktywność, na podstawie wcześniejszych wewnętrznych ocen własnej aktywności. Uczenie się jest dla mózgu (a więc i dla całego organizmu) zawsze uczeniem się na podstawie powodzenia lub niepowodzenia działania, przy czym kryteria konieczne,

${ }_{17}$ G. R oth: Poznanie i realność. Realny mózg i jego rzeczywistość. Przeł. B. B a li ck i. W zb.: Radykalny Konstruktywizm; Das Gehirn und seine Wirklichkeit. Kognitive Neurobiologie und ihre philosophischen Konsequenzen. Frankfurt am Main 1996.

${ }_{18}$ G. R o th, Gehirn und Selbstorganisation. W zb.: Selbstorganisation. Aspekte einer wissenschaftlicher Revolution. Hrsg. W. Kr o h n, G. Kü p p e r s. Braunschweig 1990, s. 167 n.

19 Ibidem, s. 178. 
by stwierdzić powodzenie danego działania, także podlegają takim kryteriom. Tak rozumiana samoreferencyjność odróżnia zasadniczo mózg człowieka i innych zwierząt od najnowszych nawet, ,uczących się" komputerów, których reguły uczenia się zadane są z góry, co znacząco ogranicza ich możliwość samokształcenia. Rzecz jasna, z technicznego punktu widzenia nie jest niemożliwe zbudowanie samoreferencyjnych komputerów. Jednakże jak tylko rozpoczęłyby one samodzielnie rozwijać kryteria oceny własnego działania, zyskałyby podobny zakres autonomii i nieprzewidywalności, jaki mają ludzie i zwierzęta ${ }^{20}$.

Pamięć, a więc doświadczenie wcześniejszych stanów oraz konsekwencji przeprowadzonych w związku z nimi działań, jest nierozłącznym elementem działania tego systemu i ,przenika” jego pracę od poziomu np. prostych wrażeń wizualnych, aż po skomplikowane obserwacje złożonych fenomenów i generowane na tej podstawie sekwencje działań.

Kolejną, ważną dla rozumienia pamięci z perspektywy mózgu kwestią jest szczególny sposób pracy tej ogromnej sieci neuronów i ich połączeń: holistyczność. Jednym ze schematów organizacji mózgu jest model topologiczny - system organizuje swoją pracę przypisując różnym obszarom mózgu różne funkcje. Np. jeżeli sygnał nerwowy trafi do obszaru potylicznego, będzie traktowany jako podstawa do wytworzenia obrazu. Jednakże równocześnie mózg pracuje jako całość lub zespół różnych obszarów, a zasadę tę nazywa się konektywnością (łączliwością) - oznacza ona, że na operacjach (np. percepcyjnych) pierwszego rzędu, które opierają się na prostych, utrwalonych wcześniej schematach, nadbudowane są operacje drugiego rzędu, których rolą jest obserwowanie tych pierwszych. Dwa poziomy obserwacji pozwalają na przeprowadzanie działań kognitywnych na własnych stanach wzbudzenia. Prostym przykładem takiego działania jest reakcja na słowo - kiedy je percypujemy, nie postrzegamy jedynie ciągu liter (bądź dźwięków), lecz uruchamiamy całą sieć skojarzeń i wcześniejszych doświadczeń związanych z tym fenomenem. Ponadto istnieje także szczególna relacja między operacjami naszego mózgu a operacjami kognitywnymi, których jesteśmy świadomi: każdej świadomej operacji kognitywnej można przypisać określoną liczbę wzbudzeń nerwowych systemu, jednakże nie każdej sieci wzbudzeń w systemie można przypisać świadomy akt kognicji. Wszystko to sprawia, że nie da się przyporządkować naszym wrażeniom i przeżyciom równoległych i odpowiadających im wzajemnie procesów neuronalnych. To, jak sami postrzegamy nasze zachowanie i działanie, nie musi mieć żadnego związku z tym, jak działa nasz mózg.

Jednym z takich ,samoobserwacyjnych” mitów, który jest jako hipoteza nie do utrzymania przy obecnej wiedzy o działaniu naszego systemu nerwowego, jest wyobrażenie pamięci jako magazynu. Wydawać by się mogło, że ta leciwa już metafora dawno straciła na znaczeniu, tymczasem, jak pisze Hejl, za sprawą silnego funkcjonowania komputerów w naszym życiu nawet nowsze badania dotyczące pamięci opierają się na takim jawnym bądź ukrytym obrazowaniu ${ }^{21}$. Na pierwszy rzut oka oczywista, metafora pamięci-magazynu natrafia $\mathrm{w}$ istocie na bardzo poważne trudności już na poziomie ściśle teoretycznym, choć, jak wiadomo,

${ }^{20}$ G. R o th, Neuronale Grundlagen des Lernens und des Gedächtnisses. W zb.: Gedächtnis. Probleme und Perspektiven der interdisziplinären Gedächtnisforschung. Hrsg. S. J. S c h mid t. Frankfurt am Main 1996, s. 147.

${ }^{21}$ P. M. H e j 1, Wie Gesellschaften Erfahrungen machen oder: Was Gesellschafttheorie zum Verständnis des Gedächtnisproblems beitragen kann. W zb.: jw., s. 300. 
żadne badania empiryczne nie potwierdziły występowania takiego obszaru w naszym systemie nerwowym, który odpowiadałby za pamięć. Pisze Hejl, że hipoteza o pamięci działającej na zasadzie magazynu pociąga za sobą wiele innych hipotez, których przyjęcie natrafia na liczne paradoksy. Przede wszystkim model taki zakłada, że doświadczenia, to, czego się uczymy, itd. składowane są w magazynie jako takie - słowa jako słowa, obrazy jako obrazy - jest to zatem zarazem założenie epistemologii obiektywistycznej, w której umysł „odbija” zewnętrzny wobec niego świat. Wraz z tezą o takiej działalności mózgu pojawia się pytanie, skąd bierze się w nim wiedza konieczna do posegregowania, skatalogowania, składowania i udostępniania pozyskanych w ten sposób „treści pamięci”? Jeżeli nie przyjmujemy koncepcji systemu samoreferencyjnego jako modelu działania mózgu i umysłu, wówczas siłą rzeczy dochodzimy do wniosku, że nasz mózg to maszyna trywialna - jest programowalny, otwarty na zalew informacji z zewnątrz, skazany na składowanie informacji o zewnętrznej referencji ${ }^{22}$.

Maturana pisze wprost: „Pamięć, jako spichlerz reprezentacji środowiska, które mogłyby być przywoływane w zależności od potrzeb, nie istnieje jako funkcja neurofizjologiczna" ${ }^{23}$. Przyjmuje się raczej, że trwałe struktury kognitywne są pewną potencjalnością, dyspozycją systemu do syntetyzowania zachowań. Funkcją pamięci zatem nie jest utrwalanie „minionego”, lecz udział w syntezie zachowania podtrzymującego autopojezę organizmu. Roth przyjmuje, że ze względu na elastyczność całego systemu nerwowego można powiedzieć, iż za pamięć odpowiadają wszystkie obszary mózgu. Można, co prawda, wyodrębnić takie jego części, które biorą udział w każdym akcie ,zapamiętywania” (jak hipokamp czy ciało migdałowate - to ostatnie odpowiedzialne jest najprawdopodobniej za kryteria emocjonalne i ,znaczniki” emocjonalne pamięci), można także wskazać, czego dowodzą z kolei szczególnego rodzaju schorzenia, że pamięć twarzy i czynności językowych da się dość łatwo wyodrębnić. Są to jednakże wyjątki potwierdzające regułę. Pisze Roth:

Spór o „centrum” stał się w świetle badań neurofizjologicznych ostatnich dziesięcioleci dalece bezprzedmiotowy. Wszystko wskazuje na to, że wiele funkcji mózgu jest rezultatem sieci wielu „centrów” z bardzo skomplikowanymi mechanizmami sterowania i kompensacji, z której wynika charakterystyczna zwłaszcza dla bardziej rozwiniętych ssaków zaskakująca plastyczność. To samo dotyczy pamięci. Wiadomo już dziś, że ze względu na różne modalności zmysłów i typy uczenia się istnieją różne rodzaje pamięci, które częściowo lokalizowane są w różnych obszarach, w aktywnościach określanych zbiorczo jako „pamięć” biorą jednakże udział wszystkie części mózgu ${ }^{24}$.

Zdaniem neurobiologa, nie można uznać poszczególnych neuronów za zbiorniki pamięci, za to o wiele bardziej uzasadnione wydaje się założenie, że dane „treści” pamięci reprezentowane są poprzez uporządkowane zachowania całych związków nerwowych. Żeby zrozumieć, jak działa ów system, należy zdać sobie sprawę, iż w każdej chwili aktywuje on rozliczne swoje centra i nie rozdziela operacji, które my zwyczajowo uważamy za odmienne czynności. Przykładem jest

22 Ibidem, s. 302.

${ }^{23}$ M a turana,op. cit., s. 62.

${ }^{24}$ G. R oth, Neurobiologischen Grundlagen des Lernens und des Gedächtnisses. FEoLL. Paderborn 1975, s. 32. Cyt. za: S. J. S c h mi dt, Gedächtnisforschungen: Positionen, Problemen, Perspektiven. W zb.: Gedächtnis, s. 24. 
ścisły związek uczenia się z pamięcią: uczenie się z systemowego punktu widzenia to zwiększanie frekwencji przepływu sygnału przez ścieżki połączeń nerwowych, które wywołuje zmiany w działaniu całego systemu. Roth ujmuje to w ten sposób:

Wszystkie procesy uczenia się łączy w mózgu to, że aktywność neuronalna prowadzi do utrwalających się zmian w systemie, powodujących modyfikacje zachowania. Uczenie się można zatem określić jako następujące po sobie, uzależnione od aktywności zmiany w przebiegu funkcji w mózgu. Program, według którego koordynowane są owe przebiegi w mózgu, opiera się na specyficznych wzajemnych stosunkach komórek nerwowych. Stosunki te z kolei określa znów wzór przełączeń oraz aktywność poszczególnych połączeń. Inaczej niż w systemach technicznych - nie można w mózgu odróżnić sprzętu od oprogramowania. P r o g r a m tkwi w architekturze całego syste mu. Wynika z tego, że każda zmiana programu, każdy proces uczenia się opierać się musi na modyfikacji wzajemnych oddziaływań między komórkami nerwowymi ${ }^{25}$.

Materialne ,przełączniki” neuronów i całych obszarów nerwowych są podstawą dla procesów pamięci i uczenia się, nie pozwalają wszakże ani jednego, ani drugiego zlokalizować w geografii mózgu. Dopiero bardzo złożone współoddziaływanie sprzężonych obszarów, sterowanych w dużej mierze przez system limbiczny, umożliwia powstanie zarządzanego przez mózg kompleksu wzajemnie uzupełniających się funkcji, które określamy jako pamięć i uczenie się. Badania przypadków uszkodzeń mózgu i amnezji pokazują, że schorzenia te rozpoczynają się na ogół od systemu limbicznego. Uszkodzenia pamięci wynikają ,pierwotnie nie z uszkodzeń poszczególnych obszarów mózgu, gdzie składowane są engramy [tj. ślady pamięci - B. B.], lecz z przerwania cykli przełączeń, które umożliwiają uzależnione od aktywności zmiany w transmisji synaptycznej kory mózgowej" "26.

Kolejnym ważnym elementem konstruktywistycznej koncepcji pamięci jest stosunek złożonych i samosterownych procesów do świadomości. W jaki sposób bowiem dynamiczna struktura sprzężonych neuronów, działajaca w oparciu o ciągły ruch i przebudowę ścieżek połączeń, pozwala funkcjonować świadomości, w której dostępne są stabilne, z naszego punktu widzenia, obiekty? Przede wszystkim, jak piszą Michael Stadler i Peter Kruse, należy pamiętać, że procesy świadomości to zaledwie ułamek wszystkich procesów w systemie nerwowym oraz że są to procesy o wysokim skomplikowaniu, które nie opierają się na zasadzie prostej przyczynowości ${ }^{27}$. Badacze przyznają, że granica między tymi dwoma obszarami, jakkolwiek funkcjonalnie oczywista, nie daje się wciąż zbadać na tyle dokładnie, by można było przedstawić pełny model świadomości. Koncepcje opisujące zjawisko stabilnych obiektów pamięci (ściśle powiązane z postrzeganiem) opierają się na koncepcji atraktorów, wywodzącej się z matematycznej teorii chaosu ${ }^{28}$.

${ }^{25}$ R o th, Gehirn und Selbstorganisation, s. 15.

${ }^{26}$ W. S in g e r, Die Entwicklung kognitiver Strukturen - ein selbstreferentieller Lernprozess. W zb.: Gedächtnis, s. 125.

${ }^{27}$ M. S t a d l e r, P. Kr u s e, Visuelles Gedächtnis für Formen und das Problem der Bedeutungszuweisung in kognitiven Systemen. W zb.: jw., s. 250 n.

${ }^{28}$ Teoria chaosu opiera się w zasadzie na trzech aksjomatach: pierwszy mówi, że systemy chaotyczne działają wprawdzie deterministycznie (tzn. ich działanie jest działaniem w zupełności określonym przez prawa i reguły), ale - zgodnie z drugim aksjomatem - ich zachowanie jest mimo to praktycznie nieprzewidywalne, ponieważ na gruncie nieznanej liczby i prędkości sprzężeń zwrotnych nawet minimalne zmiany warunków wyjściowych mogą powodować maksymalne oddziaływania. Trzeci aksjomat mówi, że w takich dynamicznych systemach, gdy są one pozostawione same sobie, 
Według Stadlera i Krusego atraktory, jako samorzutne, stabilne stany systemów chaotycznych odpowiadają za to, co nazywamy ,znaczeniem”. Atraktory powstają z wewnętrznej dynamiki procesów, znajdując optymalne wielkości, przy minimalnym zużyciu energii - są to porządki samorzutne, które utrzymują swoją stabilność w zależności od stabilności całego systemu, dopuszczającego ich powstanie. Koncepcja atraktorów (która odpowiada z grubsza psychologicznemu pojęciu schematu poznawczego) pozwala wyjaśnić płynność pamięci, a także pewną grupę złudzeń wzrokowych, określanych jako „obiekty multistabilne”. Są to np. obrazy, których treść mogą stanowić różne obiekty, a wpływ na to, jak je odbierzemy, ma zastosowany przez nas schemat poznawczy. Jednym z najsłynniejszych tego typu rysunków jest obraz Josepha Jastrowa przedstawiający królika i/lub kaczkę - w zależności od tego, jaki schemat poznawczy uruchomimy. Na takich właściwościach stabilizowania postrzeganych obiektów w naszej kognicji opiera się także współczesna sztuka malarska, np. surrealizm.

Fenomen, który zwykliśmy, jako świadomi „użytkownicy” naszego mózgu, nazywać pamięcią, umieszcza się w RK w porządku wspomnień („Erinnerung”). Maturana pisze:

To, co obserwator nazywa „,wspomnieniem” lub „pamięcią”, nie może oznaczać procesu, w którym obserwator konfrontuje każde nowe doświadczenie z kumulowaną wiedzą o swoim środowisku, lecz jest wyrazem zmodyfikowanego systemu, gotowego syntetyzować zachowanie relewantne dla aktualnego stanu aktywności systemu ${ }^{29}$.

Pogląd, którego treścią jest zacytowane zdanie, to w gruncie rzeczy kolejna próba odrzucenia potocznych przekonań o naturze pamięci - pamięć (jako zbiór operacji systemu nerwowego, w których utrwala się określone modele zachowań i działań) ma niewiele wspólnego z porządkiem „przypominania” czy też „wspomnień”. Gebhard Rusch, który sformułował koncepcję pamięci opierając się na konstruktywistycznym modelu kognicji ${ }^{30}$, twierdzi, że wspomnienia należy umieścić nie w planie odtwarzania wcześniejszych doświadczeń, lecz w planie postrzegania.

Zacząć trzeba od odróżnienia wrażeń zmysłowych od postrzegania. Wrażenia zmysłowe określimy jako dane, których dostarczają nam zmysły po wstępnym opracowaniu. Postrzeganie zaś oznacza uruchomienie utrwalonych schematów opracowywania danych (łączenia, eliminowania, nadawania kształtu itd.). W zeszytach do ćwiczeń dla szkoły podstawowej spotyka się czasem zadanie, które polega na połączeniu ze sobą ponumerowanych kropek, które zmieszane są z innymi nienumerowanymi kropkami. Kiedy połączymy te pierwsze według określonego cyframi porządku, otrzymamy rysunek. Trzymając się tej ilustracji, powiemy, że zmysły dostarczają nam jedynie obrazu zmieszanych kropek, dopiero postrzeganie, jako proces porządkujący wrażenie zmysłowe, pozwala rozpoznać (lub lepiej:

tj. gdy są odizolowane od środowiska, mogą się wytworzyć pewne wzory i porządki - atraktory, zwane też wartością własną. Zob. I. P r i g o g i n e, Die Gesetze des Chaos. Frankfurt am Main 1995. - H. v o n F o e r s t e r, Gegenstände: greifbare Symbole für (Eigen-)Verhalten. W: Sicht und Einsicht. Versuche zu einer operativen Erkenntnisstheorie. Heidelberg 1999.

${ }^{29} \mathrm{M}$ a t u r a n a, op. cit., s. 62.

${ }^{30}$ G. R u s c h, Erkenntnis, Wissenschaft, Geschichte. Von einem konstruktivistischen Standpunkt. Frankfurt am Main 1987, s. 290-416. 
wytworzyć) porządek w tym materiale i nakreślić schemat. Struktury, które pozwalają na taką pracę (koncepcje kognitywne, schematy, frames), są również tym, co umożliwia rozpoznawanie (osób, rzeczy, związków między obiektami itd.). Rusch określa wspomnienia jako rodzaj postrzegań („Wahrnehmung”), których synteza nie musi się wiązać ze stymulacjami sensorycznymi. Wspomnienia są podobne do rozpoznawania, z tym zastrzeżeniem jednak, że brakuje im charakterystycznego kontekstu postrzegania zmysłowego. Oznacza to, że za powstawanie wspomnień odpowiedzialne są tego rodzaju mechanizmy, jakie biorą udział w wytwarzaniu postrzegania wrażeń zmysłowych - czyli tak jak dokonujemy selekcji widzianych kropek, wybierając tylko te, które się układają w całość, tak i analogicznej selekcji dokonujemy przypominając sobie jakieś zdarzenie. Rusch mówi wprost, iż zamiast używać sformułowania „sięganie do pamięci” powinniśmy stosować wręcz określenie „elaboracja wspomnień” - różnica polega na tym, że rolą tego typu postrzegania nie jest przywołanie minionych zdarzeń lub doświadczeń takimi, jakie były „naprawdę”. Jego rolą jest podnoszenie spójności aktualnie czynionych działan - jako system biologiczny nie funkcjonujemy ani w przeszłości, ani w przyszłości. Do przeprowadzenia działań konieczna jest jednakże sekwencyjność: nawet najprostsze czasem czynności, które wykonujemy codziennie, wymagają od naszej kognicji, żeby porządkowała kolejne etapy realizacji działania, rejestrując krok poprzedzający aktualny etap realizacji i przewidując konsekwencje aktualnego kroku dla kroku następnego. Sekwencyjność działań, towarzysząca jej praca kognicji, rekurencyjność działania systemów samoreferencyjnych oraz komunikacyjna konieczność stabilizowania opisów własnych są jednocześnie źródłem reifikacji procesu działania - innymi słowy: źródłem pojęcia przeszłości, teraźniejszości i przyszłości. Czytamy w definicji Ruscha:

Wspomnienia (w formie, w jakiej jawią się świadomości) nie są elementami pamięci jako funkcji neurofizjologicznej i psychologicznej. Są one raczej, podobnie jak postrzegania i wyobrażenia [Vorstellung], syntetyzowane w skomplikowanej współgrze kognitywnych struktur i procesów jako specyficzny typ fenomenów świadomości. Czasowa stabilność struktur kognitywnych, skorelowanych z takimi fenomenami świadomości (jako trwała aktywność bądź reaktywność), jest przy tym koniecznym, ale niewystarczającym warunkiem. Wydolności pamięciowe organizmu wykraczają dalece poza jego świadome możliwości przypominania ${ }^{31}$.

Pojawiające się w świadomości wrażenie zmysłowe opatrzone modu s e m przes złośc i może zostać wzmocnione poprzez koncentrację na nim uwagi oraz przez jego werbalizację. Wszelkie formy „materializacji” wspomnień, niezależnie od tego, czy tylko ustne, czy również pisemne, są szczególną formą e 1 a b o r a c j i w s p o m n i eń, tj. nadania im określonej formy i uporządkowania materiału w ten sposób wytworzonego.

Rezultatem takich elaboracji może być opowiadanie jako próba sformułowania i reifikacji tzw. przeszłości, która jawi się nam jako główny cel pamięci. Tym samym elaboracje pamięci podlegają działaniom, wynikającym z nadawania im formy opowiadania, m.in. kompensacji, która jest nieodzowną cechą wszelkich działań poznawczych ${ }^{32}$. Materializacja wytworzonych tą drogą wspomnień staje się jednocześnie elementem intersubiektywnym - żeby sformułować wrażenie zmysłowe

${ }^{31}$ G. R u s c h, Erinnerungen aus der Gegenwart. W zb.: Gedächtnis, s. 284.

${ }^{32}$ Zob. ibidem, s. 286. 
w postaci wspomnienia, trzeba użyć narzędzi: pierwszym i najbardziej oczywistym narzędziem jest język, który jako narzędzie komunikacji wynika z - wspomnianej już wcześniej - paralelizacji struktur kognitywnych jednostek pozostających w interakcji. Pierwszym zatem uporządkowaniem, któremu podlegają treści pamięci, są struktury językowe - nawet jeżeli dokonując elaboracji wspomnień wytworzymy wrażenia obrazu, zapachu, motoryki ciała itd., to i tak ich komunikowanie się w środowisku społecznym oznacza wykorzystanie językowych sposobów wyrażania. Kolejnym uporządkowaniem wspomnień są bardziej złożone struktury i formy opowiadania, jeżeli zaś jesteśmy uczestnikami społeczeństwa - takiego jak społeczeństwo polskie na początku XXI w. - wówczas dysponujemy nie tylko formami porządkowania wspomnień, lecz także formami, które mają określone tradycje, użycia, a zarazem funkcjonują w określonych i dynamicznie zmieniających się mediach. Innymi słowy: wstępując do struktur społecznych, dostosowując strukturę naszej kognicji do interakcji, podlegając socjalizacji na różnych poziomach organizacji społecznej (od rodziny po zespół badawczy na uniwersytecie), uczymy się - począwszy od języka, a skończywszy na skomplikowanych strukturach narracyjnych (dzienniki, wspomnienia, pamiętniki, życiorysy itd.) - jak opracowywać wrażenia zmysłowe, których nasza kognicja dostarcza nam na podstawie neuronalnych ,pozostałości” po wykonanych działaniach. Jeżeli zdamy sobie sprawę, jak długa jest droga kognitywna, prowadząca od warunków środowiskowych, w których powstało dane zdarzenie, poprzez jego percepcję i postrzeganie przez system kognitywny, poprzez walidację danego doświadczenia (nowe/znane, ważne/nieważne), utrwalenie jego śladu w zmiennych przebiegach połączeń nerwowych, wreszcie elaborację wrażenia zmysłowego wytwarzanego pod presją pragmatyki ,tu i teraz” i jego materializację za pomocą narzędzi interakcji społecznej, wymuszających konwencjonalną kompensację luk w logicznym porządku wydarzeń - to tylko z bardzo wielkim trudem zdołamy utrzymać tezę, że wspomnienia odsyłają nas do wydarzeń obiektywnie zaistniałych w przeszłości. Jest wysoce wątpliwe, czy odsyłają nas nawet do wrażeń subiektywnych. O wiele rozsądniejszym i prostszym wnioskiem płynącym z analizy omawianego modelu pamięci indywidualnej jest wniosek o konstruktywnym charakterze naszej tzw. pamięci, która jako aktywność poznawcza i kognitywna - nie służy obiektywizacji przeszłości, lecz udziałowi w społecznej grze. W tym sensie nie pamiętamy, lecz przypominamy sobie, a podstawą elaboracji wspomnień jest aktualny stan naszej kognicji i systemu nerwowego.

\section{Pamięć społeczna}

Dopełnieniem konstruktywistycznych dociekań o pamięci jest koncepcja pamięci społecznej Hejla ${ }^{33}$. Twierdzi on, opisując - jak Talcott Parsons - jednostki

${ }^{33}$ Koncepcję tę należy odróżnić od koncepcji systemów społecznych N. Luhmanna, którego często przedstawia się jako „konstruktywistę” wśród socjologów, co jest dużym uproszczeniem. Zdumiewający i niewątpliwie cenny dorobek Luhmanna w obszarze systemowych modeli społeczeństwa nie wynika jednak z prostej kontynuacji konstruktywistycznego stylu myślowego, co on sam często podkreślał i co wynika choćby z jego stosunku do koncepcji autopojezy. Luhmann twierdził, że system społeczny jest autopojetyczny, co pozostaje w sprzeczności z intencją Maturany, który cechę tę przypisywał wyłącznie organizmom żywym. Zob. N. L u h m a n n, Systemy społeczne: 
społeczne jako jednostki analityczne, że systemy społeczne powstają z wielkości dwóch rodzajów: komponentów i organizacji, którą komponenty stwarzają. O systemie społecznym możemy mówić wtedy, gdy pewna liczba uczestników społeczeństwa wytwarza (lub przejmuje) wspólną konstrukcję rzeczywistości i oddziałuje na siebie wzajemnie w pośrednim lub bezpośrednim odniesieniu do niej. Tego rodzaju wytwory wynikają z procesów negocjacji społecznej, zawierają społeczne modele działań i normy i są fundamentem wspólnotowości dla danej grupy uczestników (czyli systemów kognitywnych zorganizowanych samoreferencyjnie). Ponieważ wszystkie działania w systemie społecznym odnoszą się do określonej konstrukcji rzeczywistości i jej przypisanych modeli działania i norm, Hejl określa system społeczny jako synreferencyjny (tj. będący wypadkową samoreferencji kognicji komponentów i samoreferencji organizacji społecznej). W momencie, gdy jednostki wytwarzają wspólną rzeczywistość, stają się jej aktywnymi komponentami, siłą rzeczy podlegającymi podwojonemu uporządkowaniu systemowemu przez system społeczny, który współtworzą, oraz przez system kognitywny, który charakteryzuje jego uczestnika jako byt autonomiczny ${ }^{34}$.

Systemy synreferencyjne charakteryzuje selektywność oraz relatywna niezależność ich komponentów, tzn. że system ogranicza wpływ na swoją strukturę zarówno czynników zewnętrznych (środowiska), jak i wewnętrznych (komponentów). Hejl wpisuje się tym samym w tę tradycję socjologiczną i filozoficzną, w której społeczeństwo nie jest traktowane jak zbiór wolnych jednostek związanych ze sobą umową społeczną (Rousseau, Hobbes, Kant), lecz jako fenomen natury, wynikający z naturalnych procesów samoorganizacyjnych (tradycja Comte’a i współczesnej socjologii naukowej). Sięga zresztą do tradycji, odwołując się, w kontekście rozważań o pamięci, do problemu różnicowania się społeczeństwa - za podstawę przyjmuje tu rozróżnienie na wspólnotę (,Gemeinschaft”) i społeczeństwo (,Gesellschaft').

Na poziomie organizacji systemowej w s p ó ln ot ę charakteryzuje ograniczona liczba uczestników, gęsta sieć interakcji, jeden obowiązujący obraz świata i związana z nim homogenizacja zachowań jego komponentów. Wspólnotę charakteryzuje ponadto dominująca rola religii i tradycji, integracja doświadczeń indywidualnych na poziomie społecznym, łatwość komunikacji oraz niski potencjał konfliktu. Członków wspólnoty cechuje niewielki stopień indywidualności, co oznacza duże podobieństwa w sposobach reagowania na zdarzenia zewnętrzne i swoistą ,solidarność mechaniczną”. Wspólnotowość charakterystyczna jest zwłaszcza dla niepiśmiennych pierwotnych grup społecznych, w których rzeczywistość stabilizuje się za pomocą pamięci indywidualnej oraz zrytualizowanej i ściśle przestrzeganej obrzędowości. Pamięć społeczna zależy tu w dużej mierze od możliwości elaborowania wspomnień przez najstarszego uczestnika wspólnoty, przy czym wiedza nie jest zbierana i kumulowana po to, by ją dowolnie przywołać, lecz podlega ciągłej aktualizacji z punktu widzenia aktualnego stanu systemu. Wiedza osadza się ostatecznie w łatwych do zapamiętania narracjach mitycznych

zarys ogólnej teorii. Przeł. M. K a c z m a r c z y k. Kraków 2007. - H e j 1, Wie Gesellschaften Erfahrungen machen [...].

${ }^{34}$ Granica między oboma porządkami systemowymi dotyka w istocie jednego z kluczowych problemów nauk społecznych, czyli współwystępowania procesów integracji i indywidualizacji. 
i obrzędowych, które stają się podłożem wspólnej i bardzo konserwatywnej konstrukcji rzeczywistości.

S p ołe c z eńs two, w jego typie idealnym, jest właściwie zaprzeczeniem wspólnoty: może posiadać nieograniczoną liczbę członków, m.in. dlatego, że konstrukcja rzeczywistości jako twór podlega lokalnym reinterpretacjom; nigdy nie dochodzi do interakcji wszystkich ze wszystkimi, siłą rzeczy więc pojawia się selektywność i hierarchiczność struktur społecznych, kosztem osłabienia roli religii i siły oddziaływania tradycji. Zachowanie członków społeczeństwa wykazuje w ramach tegoż społeczeństwa znaczące różnice, wzrasta ich indywidualność i rośnie niepewność w podejmowaniu decyzji, zwiększa się także potencjał konfliktu. Komunikacja jest zróżnicowana: powstają subsystemy, które dostosowują modele komunikacji do lokalnych potrzeb, przy czym poszczególny uczestnik społeczeństwa może przynależeć i realizować modele komunikacyjne wielu subsystemów społecznych. Ważną, także w kontekście problemu pamięci społecznej, cechą rozwiniętych systemów społecznych jest ich dynamiczny charakter - są one bowiem, z jednej strony, stabilizowane poprzez zwiększoną selektywność organizacji systemowej, z drugiej strony jednak - rosnący indywidualizm uczestników (komponentów) społeczeństwa może prowadzić do sytuacji, w której zmiany w obszarach komponentów prowadzą do procesów reorganizacji ponadindywidualnych struktur społecznych. Jak pisze Hejl:

Modulacja dynamiki komponentów, tzn. wynikające z doświadczeń społecznych przemiany punktów widzenia oraz jawiących się z tej perspektywy działań, pozostaje dla organizacji systemu nieznacząca tak długo, jak długo nie zostanie przekroczony poziom ich widoczności [Auffälligkeitniveau], który jest w każdym systemie określany inaczej. Wiedzie to do fenomenu autonomizacji organizacji w stosunku do indywidualnych działań komponentów. Jeżeli jednak poziom ten zostanie przekroczony i nie dojdzie przy tym do wykluczenia danego członka systemu, wówczas następują procesy reorganizacyjne [...]. Tego rodzaju przemiany prowadzą do całej kaskady procesów dostosowawczych, aż do momentu kiedy labilny układ stosunków zoptymalizuje się w stanie równowagi ${ }^{35}$.

Innymi słowy, cechą charakterystyczną systemów społecznych, które nie są poddane „rygorom” właściwym wspólnocie, jest dynamika oparta na sprzężeniu zwrotnym między aktywnością w obszarze jego komponentów a organizacją systemu, częściowo tylko autonomiczną lub też posiadającą autonomiczność czasową.

Jak się nietrudno domyślić, dynamiczna struktura społeczna wpływa także na specyfikę społecznego obszaru doświadczeń - w tym pamięci. Ponieważ w społeczeństwie za sprawą selektywnej organizacji nikt nie jest w stanie doświadczać wszystkich zdarzeń, relewantnych dla systemu, różnicowaniu podlegają także postrzeganie społeczne i reakcja na zewnętrzne bodźce, choć schemat reakcji okazuje się ten sam - dany input, który jest postrzegany w przestrzeni wspólnej określonej dynamicznej struktury społecznej, podlega opracowaniu zgodnie z aktualnym stanem jego organizacji. Hejl przywołuje przykład przedsiębiorstwa, które w zależności od tego, w jakiej jest kondycji finansowej i jakie ma możliwości reorganizacji, może różnie zareagować na pojawienie się innowacji na rynku. Albo może być zainteresowane jej przyjęciem i wprowadzeniem do własnego cyklu produkcji, albo może ją postrzegać jako zagrożenie, kiedy nie ma dość środ-

${ }^{35} \mathrm{He} \mathrm{j}$ 1, Wie Gesellschaften Erfahrungen machen [...], s. 315. 
ków, żeby tę innowację przyjąć. Społeczeństwa, podzielone na subsystemy, należy zatem opisywać za pomocą ich aktualnych „stanów”, które z kolei nie są fenomenami izolowanymi, lecz powstają w dynamicznych sieciach między komponentami - właściwość określającą przyjęcie bądź aktywowanie danych stosunków interakcyjnych nazywa się (podobnie jak to miało miejsce w przypadku systemu nerwowego) konektywnością (związkami oddziaływań) systemu ${ }^{36}$. Hejl odróżnia od siebie konektywności pierwszego rzędu, tj. takie, które są historycznie wypracowanymi modelami interakcji i reakcji na impuls z zewnątrz oraz konektywności drugiego rzędu, których zadaniem jest dokonywanie selekcji konektywności pierwszego rzędu, co z kolei pozwala ustalić schematy reagowania na impuls z zewnątrz zgodnie z porządkiem (synreferencją) systemu społecznego. Oznacza to, że system przypisuje znaczenie określonemu impulsowi z zewnątrz zgodnie $\mathrm{z}$ aktualnym stanem nadbudowanych na sobie związków oddziaływań jego komponentów - czyli konektywności.

Tak zdefiniowany system ,uczy się”, tj. zapamiętuje i przypomina sobie - poprzez zmianę w strukturze swojej konektywności (uczenie się) bądź uruchomienie utrwalonej już konektywności (przypominanie). Hejl podaje jako przykład obecność przedstawicieli teologii w niemieckich zespołach akademickich, mimo że tradycja rozdziału Kościoła od państwa jest w Niemczech długa. Teologowie mają swoje miejsce w nauce niemieckiej nie dzięki temu, co mówią lub robią, lecz dlatego, że na podstawie historycznie wytworzonych konektywności, które nie zostały zniesione, mogą odgrywać taką rolę - ich obecność jest właśnie pamięcią systemu akademickiego w Niemczech ${ }^{37}$.

Tego rodzaju pamięć społeczna nie przekłada się bezpośrednio na pamięć (właściwie: elaboracje wspomnień) poszczególnych uczestników systemu, lecz jest bardzo ważnym elementem współkonstytuującym indywidualne konstrukcje rzeczywistości, ponieważ ma moc przypisywania znaczenia. Skomplikowanie sytuacji jednostki w społeczeństwie podnosi fakt, że niemal zawsze jesteśmy jako członkowie społeczeństwa komponentami różnych, sąsiadujących subsystemów społecznych i podlegamy tym samym różnym konektywnościom i pamięciom społecznym. Będąc członkami rodziny, drużyny piłkarskiej, częścią zespołu w zakładzie pracy, tworząc kręgi koleżeńskie, grupy zainteresowań itd. jesteśmy także beneficjentami wielu, różnie zorganizowanych pamięci społecznych.

\section{Podsumowanie}

Z konstruktywistycznego punktu widzenia pamięć jako część praktyki życia podlega trzem dynamicznym, powiązanym ze sobą porządkom. Jako b y t y zorganizowane autopojetycznie dysponujemy systemem nerwowym, pracującym na podstawie kumulowanych doświadczeń w postaci zmiennej architektury połączeń nerwowych w naszym mózgu. Zarówno nabywanie wiedzy kodowanej elektrochemicznie, jak i jej wykorzystywanie podporządkowane są ściśle pragmatyce repro-

${ }^{36} \mathrm{~W}$ odróżnieniu jednak od systemu nerwowego, w którym pojęcie to określa cały zbiór neuronalnych interakcji, tu konektywność opisuje wirtualną przestrzeń interakcji komponentów systemu - ich potencjalną zdolność do komunikowania się.

${ }^{37} \mathrm{H}$ e j 1, Wie Gesellschaften Erfahrungen machen [...], s. 327. 
dukcji i przetrwaniu organizmu. Jako św ia d o me jednostki, posiadające kognicję zdolną do obserwacji otoczenia i przeprowadzania działań, dysponujemy umiejętnością elaboracji wspomnień - podobnych do wrażeń zmysłowych fenomenów świadomości, które wykorzystują jedynie znikomą ilość wiedzy „magazynowanej" przez nasz system nerwowy. Wytwarzając wspomnienia, materializując je za pomocą mediów (języka, pisma, tekstu), dostosowujemy ich formę do społecznych środków wyrazu, które, z jednej strony, umożliwiają nam obserwację nas samych, z drugiej - pozwalają nam brać udział we współtworzeniu rzeczywistości społecznej. Wreszcie jako k omp onenty systemów społecznych sami stajemy się, poprzez zanurzenie w sieci międzyludzkich organizacji, nośnikami pamięci społecznej - struktur porządkujących nasze działania i opisujących nasze miejsce $\mathrm{w}$ rzeczywistości. Na żadnym $\mathrm{z}$ tych poziomów organizacji pamięć nie służy przenoszeniu doświadczeń w czasie, nie służy magazynowaniu raz pozyskanej wiedzy, lecz jest potencjalnością systemową, która pozwala na syntetyzowanie działań i kształtowanie egzystencji ,tu i teraz”. Linearne i przestrzenne metafory naszej przeszłości czy też narracyjne obrazy przebiegu naszego życia wytwarzają w nas przeświadczenie, że mamy dostęp do tego, co „było”, z perspektywy tego, co ,jest”. Przeszłość jest iluzją teraźniejszości, potrzebną i użyteczną funkcją naszego przebywania w świecie, jest obiektem podlegającym negocjacji społecznej. My nie tyle używamy przeszłości do aktualnych celów - my ją stwarzamy, by móc się potem do niej odnieść. Jak głosi znane porzekadło, życie jest sztuką w miarę doskonałego samooszukiwania się - z konstruktywistycznego punktu widzenia jednakże nie jest to powód do troski.

Abstract

BOGDAN BALICKI

(University of Szczecin)

\section{MEMORY IN RADICAL CONSTRUCTIVISM PERSPECTIVE}

The article presents the concept of memory within the limits of Radical Constructivism. In the first part the author describes the characteristics of this approach and its attitude to the classical conceptions of cognition and knowledge. Radical Constructivism is viewed as a trend in philosophy of science which derives human cognitive abilities from his biological nature and autopoietic organisation, which justifies the view that human cognitive system is a closed system that shapes knowledge about the world in the form of action construct models of the natural world. In the second part the author discusses constructivist models of memory, understood as a neurological, consciousness, and social phenomenon. The memory seen from a neurological perspective is contained in the architecture of neural connections, as a matter of consciousness it is defined as an ability of memories elaborations and their arrangement for social negotiations, while social memory is explicated by structures of units interaction bound by supra-individual relations of systemic nature. 